\title{
Surgical management of spheno-orbital meningiomas
}

\author{
Peerooz Saeed
}

Received: 15 April 2011 / Accepted: 19 April 2011 / Published online: 7 May 2011

(C) The Author(s) 2011. This article is published with open access at Springerlink.com

\section{Dear Editor,}

Dr. Nagatani and colleagues, in their comments on our study of natural history of sphenoid-orbital meningiomas (SOM) [8], have recommended not resecting the portion of SOM involving cavernous sinus (CS) and superior orbital fissure (SOF) in order to avoid the risk of permanent cranial nerve dysfunction.

As indeed pointed out, the resection of SOMs is associated with a range of complications.

The reported numbers of postoperative neurological complications after resections of SOMs (primarily cranial nerve palsies) range up to $100 \%$ for trigeminal hypesthesias $[3,9], 13 \%$ for oculomotor palsy $[2,5,10]$, and up to $6 \%$ mortality have also been reported $[2,5]$. Furthermore, a recurrence rate of up to $50 \%$ after a surgical resection has been reported [1].

As we have explained in our recent paper on the surgical results of SOM [7], given the limited improvement in prognosis and the complications involved in surgery, the aim of surgical treatment for SOM should be restoration of visual acuity and reduction of proptosis, rather than complete tumor removal.

In our group of 66 patients, surgery arrested visual deterioration or improved visual acuity in $91 \%$ of our patients. Furthermore, a substantial reduction in proptosis was achieved in $85 \%$ of the patients. Proptosis was reduced by $2.6 \pm 2.6 \mathrm{~mm}$; however, we had hoped to achieve a better result and were disappointed by this level of improvement [7].

P. Saeed $(\bowtie)$

Orbital Center, Academic Medical Center,

University of Amsterdam,

P.O. Box 22660, 1100 DD Amsterdam, The Netherlands

e-mail: p.saeed@amc.uva.nl
To resect SOM, different surgical approaches are used, including transzygomatic, pterional, frontotemporal, combined transcranial-transmalar, and cranio-orbital approaches. All of these approaches allow sufficient access to the orbit and middle fossa base for bony and soft-tissue tumor resection, as well as decompression of the SOF and optic canal $[1-3,5,7,9,10]$.

The surgical approach can be tailored to the individual case. Decompression of the optic canal can be achieved through a frontotemporal approach combined with orbitozygomatic $(\mathrm{OZ})$ or a frontotemporal approach alone. We recommend that the frontotemporal approach combined with $\mathrm{OZ}$ be reserved for cases that require wide surgical exposure.

Recently, Lund and Rose [4] reported 12 patients with SOM who underwent endoscopic endonasal medial orbital wall decompression and decompression of the optic canal in eight patients with opticopathy and visual deterioration. In these patients, the opticopathy improved and the visual acuity improved by one to four lines on the Snellen chart.

In our view, a craniotomy for debulking is not indicated for patients who have mild proptosis or no visual deterioration. Also, when the major symptom is proptosis without optic canal stenosis, an extended lateral orbitotomy alone can be preformed to avoid the complications of a craniotomy. Extended lateral orbitotomy or total lateral orbitotomy has been used routinely for severe cases of Graves' orbitopathy and tumors in the orbital apex [6, 7].

Because the majority of SOMs are resected sub-totally, radiotherapy should be considered as an adjuvant treatment for SOM, as postoperative radiotherapy might give a better control of tumor growth, with minor side effects.

When there is an extension of SOM to CS, we do not recommend a surgical intervention of that portion of tumor, and radiotherapy should be considered. However, the 
hyperostotic bone around SOF can be excised safely, without damaging cranial nerves. In conclusion, like Dr. Nagatani and colleagues, we recommend in the surgical resection of SOM a symptom orientated approach as opposed to a radical resection, as extensive surgical resection can be associated with significant postsurgical morbidity.

\section{Conflicts of interest None.}

Open Access This article is distributed under the terms of the Creative Commons Attribution Noncommercial License which permits any noncommercial use, distribution, and reproduction in any medium, provided the original author(s) and source are credited.

\section{References}

1. Bonnal J, Thibaut A, Brotchi J, Born J (1980) Invading meningiomas of the sphenoid ridge. J Neurosurg 53:587-599

2. Carrizo A, Basso A (1998) Current surgical treatment for sphenoorbital meningiomas. Surg Neuro 150:574-578
3. Honeybul S, Neil-Dwyer G, Lang DA, Evans BT, Ellison DW (2001) Sphenoid wing meningioma en plaque: a clinical review. Acta Neurochir (Wien) 143:749-757

4. Lund VJ, Rose GE (2006) Endoscopic transnasal orbital decompression for visual failure due to sphenoid wing meningioma. Eye (Lond) 20:1213-1219

5. Ringel F, Cedzich C, Schramm J (2007) Microsurgical technique and results of a series of 63 spheno-orbital meningiomas. Neurosurgery 60:214-221

6. Rootman J, Stewart B, Goldberg RA (1995) Orbital surgery: a conceptual approach. Lippincott-Raven, Philadelphia

7. Saeed P, van Furth WR, Tanck M, Freling N, van der Sprenkel JW, Stalpers LJ, van Overbeeke JJ, Mourits MP (2011) Surgical treatment of sphenoorbital meningiomas. $\mathrm{Br} \mathrm{J}$ Ophthalmol. doi:10.1136/bjo.2010.189050

8. Saeed P, van Furth WR, Tanck M, Kooremans F, Freling N, Streekstra GI, Regensburg NI, van der Sprenkel JW, Peerdeman SM, van Overbeeke JJ, Mourits MP (2011) Natural history of spheno-orbital meningiomas. Acta Neurochir (Wien) 153:395-402

9. Sandalcioglu IE, Gasser T, Mohr C, Stolke D, Wiedemayer H (2005) Spheno-orbital meningiomas: interdisciplinary surgical approach, resectability and long-term results. J Craniomaxillofac Surg 33:260-266

10. Shrivastava RK, Sen C, Costantino PD, Della RR (2005) Sphenoorbital meningiomas: surgical limitations and lessons learned in their long-term management. J Neurosurg 103:491-497 